\title{
How Effective the Employee Training Programs Are? Evidence from Government Banks of Bangladesh
}

\author{
Nazrul Islam¹, Md. Nafizur Rahman², Eshnat Mumtahina Mridha², Jasmin Sultana Sharna², Maliha Mosharraf², \& \\ Nowshin Nower ${ }^{2}$ \\ ${ }^{1}$ Canadian University of Bangladesh, Dhaka, Bangladesh \\ 2 Bangladesh University of Professionals, Bangladesh \\ Correspondence: Md. Nafizur Rahman, Department of Business Administration in Finance and Banking, \\ Bangladesh University of Professionals, Mirpur Cantonment, Dhaka 1216, Bangladesh. E-mail: \\ nafizrahman23@gmail.com
}

Received: July 9, 2020

doi:10.5539/ijbm.v15n9p57
Accepted: August 6, 2020

Online Published: August 16, 2020

URL: https://doi.org/10.5539/ijbm.v15n9p57

\begin{abstract}
This paper attempts to identify the factors concerning the effectiveness of training programs of government-owned commercial banks in Bangladesh. The banking industry of Bangladesh has witnessed tremendous growth since the country's independence. Need-based training and development of manpower have become prerequisites for the continuous growth of this sector. The prominent government banks conduct numerous training programs for the fresh recruits and the existing staff as well. A sample of 205 bank personnel who received training from the state-owned banks was surveyed through a structured questionnaire. The responses of the employees were analyzed using the Exploratory Factor Analysis and Multiple Regression Analysis techniques. This paper finds that the development of overall skills, reduction of stress level, development of technical skills, need-based training programs, long-run productivity, and quality of the instructors are the significant factors contributing to the effectiveness of training programs of government banks in Bangladesh. The finding of this study implies that the bank managers should emphasize more on the reduction of stress level, development of technical skills, need-based training programs, long-run productivity, and quality of the instructors that directly affect the effectiveness of the training programs run by the government-owned commercial banks in Bangladesh.
\end{abstract}

Keywords: government commercial bank, training and development, job stress, need-based training programs, human resource management

\section{Introduction}

The banking industry is the most organized and largest in the financial sector of Bangladesh employing over one lac employees of the country. It is the most structured industry\#al sector of Bangladesh where people's interest level in building their careers are higher. After the war of liberation, Bangladeshi governments made a constant attempt to boost the banking industry. Banking institutions have developed so extensively that they now play a pivotal role in the economic advancement. The opening up of the Bangladeshi economy has seen a profound shift in the country's banking sector (Tabassum, et. al., 2011). This has introduced higher job prospects, higher income levels, and shifts in consumer habits, and a competitive atmosphere in the country arises as a result. This sector has evolved as a lucrative sector for employment in the country during the past decade. But the continuity of the employees' careers relies on effective training which helps them develop confidence and increases productivity at work. Findings demonstrated that training programs implemented and run by this financial industry are often lacking effectiveness. There are now 57 scheduled banks in Bangladesh working under the complete regulation and supervision of Bangladesh Bank, which is authorized to do so by Bangladesh Bank Order, 1972 and Bank Company Act, 1991. This sector is composed of several banks in different categories. Considering ownership, the banking industry can be classified into the following categories which include (i) State-Owned Commercial Banks (SOCBs), (ii) State-Owned Development Financial Institutions (DFIs), (iii) Private Commercial Banks (PCBs) and (iv) Foreign Commercial Banks (FCBs). As of 2018, Bangladesh had 57 banks with 9955 bank branches across the country. At the end of June 2019, the number of total banks increased to 59 and the number of bank branches further increased to 10286. (Table 1). 
Table 1. Overview of the Banking Sector of Bangladesh (billion Taka)

\begin{tabular}{|c|c|c|c|c|c|c|}
\hline Bank Types & $\begin{array}{l}\text { Number of } \\
\text { Banks }\end{array}$ & $\begin{array}{l}\text { Number of } \\
\text { Branches }\end{array}$ & $\begin{array}{l}\text { Total } \\
\text { Assets }\end{array}$ & $\begin{array}{l}\% \text { of Industry } \\
\text { Assets }\end{array}$ & Deposits & $\begin{array}{ll}\% & \text { of } \\
\text { Deposits }\end{array}$ \\
\hline $\begin{array}{l}\text { 1. State Owned Commercial } \\
\text { Banks }\end{array}$ & 06 & 3746 & 3732.2 & 25.6 & 2868.4 & 26.6 \\
\hline $\begin{array}{l}\text { 2. State Owned Development } \\
\text { Financial Institutions }\end{array}$ & 03 & 1412 & 324.0 & 2.2 & 286.0 & 2.6 \\
\hline 3. Private Commercial Banks & 41 & 5060 & 9769.7 & 67.0 & 7127.2 & 66.0 \\
\hline 4. Foreign Commercial Banks & 09 & 68 & 747.1 & 5.2 & 517.2 & 4.8 \\
\hline Total & 59 & 10286 & 14752.9 & 100.0 & 10798.7 & 100.0 \\
\hline
\end{tabular}

Source: Bangladesh Bank, June 2019.

At present, nine state-owned banks are operating in Bangladesh that employed more than seventy thousand employees. But there is inefficiency in the human resource practices of these banks. It is often reported that the training programs conducted by these government banks are old fashioned and apparently less effective. As a result, the employees lack the skills of providing modern services to their clients. Hence, this research was designed to investigate the determinants contributing to the overall effectiveness of staff training programs of the government-owned banks in Bangladesh.

\section{Objectives of the Study}

The broad objective of this paper is to evaluate the effectiveness of employee training in the Government Banks of Bangladesh. The specific objectives are as follows.

1) To illustrate the training and development programs of the government banks in Bangladesh;

2) To identify the factors related to the effectiveness of training programs of government banks in Bangladesh;

3) To identify the significant factors concerning the effectiveness of employee training programs of government banks in Bangladesh.

\section{Literature Review}

In developing economies like Bangladesh, the banking sector acts as an important means of socio-economic transition. A well-organized banking system can play a crucial role in the country's growth. Human Resource Management is a distinctive approach to job management that aims to gain a competitive edge through the systematic mobilization of a fully dedicated and competent workforce, using an interconnected array of cultural, institutional, and manpower techniques. Extensive training and culture management programs, individually tailored performance appraisal systems, as well as a range of employee involvement mechanisms, work towards the attainment of enhanced contribution by employees. (Afroz, 2012).

The research (Chahal, 2013) showed that banks in the private sector have more effective training as compared to banks in the public sector. The research results indicate that training and efficiency increase the confidence of the employee's abilities and boost their performance and provide them the ability to gain lucrative employment and success in their work as well. The results suggest that the training aims at giving the trainee the ability to improve their habits and leads to their productivity and skills development. (Kaur, 2016) emphasized on short-term and long-term productivity enhancement, as a result of numerous training programs being implemented as goals as an important factor in the business world. One should comprehend the goals of an organization to develop training objectives that will help achieve the organization's overall business goals.

(Mohamed and Alias, 2012) examined the effectiveness of executive training programs in the banking sector in Malaysia using the four stages of the Kirkpatrick assessment model. The results also showed some indications that respondents had increased their level of knowledge and were able to contribute to their work the experience and skills gained through training. It is necessary to receive positive feedback from participants regarding satisfaction for each training program. A training program is an attempt on the part of the employer to provide employees with incentives to learn skills, behaviors, and knowledge related to work. In this modern age, banking needs to become dynamic and innovative to address the ever-growing demands of business and household, and to take this industry to the heights of international competitiveness often involves the right mix of innovative technologies and skilled and competent workers. Hence, at the time of induction, promotion, and other circumstance, most commercial banks, both private and public, undertake training and development programs. (Akilandeswari, 2014). (Islam, 2015) argued that most of the commercial banks tend to conduct beginning level 
and in house training, but they hardly conduct mid or advanced level training programs. Training effectiveness isn't static, it has to be evaluated, revised and upgraded regularly in line with demanding economic conditions, governmental policies, advances in technology, and customer expectations. (Karthikeyan et al., 2010).

The training is intended to enhance people's attitudes and efficiency. There are different forms of training programs, such as Orientation Learning, Work Training, safety training, Promotional Training, refresher course, vocational training, etc. to develop workplace skills. (Lamba and Choudhary, 2013) Trained workers are well suited to the work and the absenteeism and turnover rates are lower. Skilled workers will deliver output in both quality and quantity. Trained workers will react well and will adjust well to changing technologies. (Mahmood et al., 2014). (Masum et al., 2015) argued that one of the crucial functions of human resource management practices that can meet the changing demands of the workforce is training and development.

Since work in the banking industry has become more dynamic, the value of employee training has risen. (Megharaja, 2014). A prerequisite to ensuring sustained success in training programs is providing a comprehensive approach to measurement and assessment approaches. Acknowledgment of the training methods and measuring techniques is critical for the effective training of the organization. Management should concentrate on strengthening human resources through diverse training to promote organizational effectiveness to chase the vibrant business environments. (Rahman, 2014). (Sarker, 2014) has demonstrated that training and development programs as HRM practices influence job satisfaction and results in better organizational performance.

The literature review revealed that the factors that influence the effectiveness of training in government banks in Bangladesh are: career advancement, learning opportunity, improve knowledge level, performance improvement, skill development, increased productivity, improved working ability, awareness, adapting new challenges, approach and behavior, job rotation, convenient training system, improved commitment, job satisfaction, reduce difficulties, increase quality, organizational growth, effective communication, increase efficiency (Table 2).

Table 2. Literature review on the effectiveness of employee training in SOCBs

\begin{tabular}{|c|c|c|c|c|c|c|c|c|c|c|c|c|c|c|c|c|c|}
\hline & $\begin{array}{l}\text { Carser } \\
\text { Adarance } \\
\text { ment } \\
\end{array}$ & ${ }_{\text {operaning }}$ & 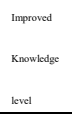 & $\begin{array}{l}\text { Performunace } \\
\text { iimporement }\end{array}$ & $\begin{array}{l}\text { Skill } \\
\text { dececoppment }\end{array}$ & productinity & $\begin{array}{l}\text { Inproved } \\
\text { working } \\
\text { abilily } \\
\end{array}$ & Avaruesess & $\begin{array}{l}\text { Adpring } \\
\text { new } \\
\text { clallenges } \\
\end{array}$ & $\begin{array}{l}\text { Apposach } \\
\text { and } \\
\text { bethroior } \\
\end{array}$ & sob & 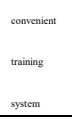 & $\begin{array}{l}\text { Inproved } \\
\text { Comminment }\end{array}$ & $\begin{array}{l}\text { Job } \\
\text { Saritifation }\end{array}$ & $\begin{array}{l}\text { Rectuce } \\
\text { Difirioulisis }\end{array}$ & $\begin{array}{l}\text { Incresased } \\
\text { Qualily }\end{array}$ & $\begin{array}{l}\text { Organizationat } \\
\text { growhih }\end{array}$ \\
\hline Chatat.2013) & & & s & $\mathrm{s}$ & v & $\mathrm{v}$ & & & & $\nu$ & & & & & & & \\
\hline Kaur (2016) & & & & 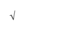 & v & v & & & & & & & & & & $\mathrm{v}$ & \\
\hline $\begin{array}{l}\text { Molahned \& Alias, } \\
\text { (2012) }\end{array}$ & & & v & & & & & & & & & & & & & & \\
\hline Avilinatersari, (2014) & & & $\checkmark$ & $v$ & $\checkmark$ & & & & & $v$ & & & s & & & & \\
\hline Atmed \& \&udinin (2012) & & & & 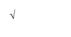 & & v & & & & & v & & & $\mathrm{s}$ & & & \\
\hline stalam, (2015). & & & $\checkmark$ & $\checkmark$ & & & & & v & & & & & & & & \\
\hline Meghanas, 20144) & & & & & $\mathrm{s}$ & $\mathrm{v}$ & & & & & & & v & s & $\mathrm{v}$ & & \\
\hline Akeros, etat (2012) & & & & $\checkmark$ & & $\checkmark$ & & & & & & & & & & & \\
\hline 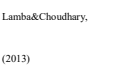 & $\checkmark$ & & & & & v & & & & & & & s & $v$ & & v & \\
\hline Atatar, S S Shah, (2015) & & & v & v & v & & $\checkmark$ & & & & & & & $v$ & & & \\
\hline Rahman, (2014) & & & & & & & & & $v$ & & & & & $\checkmark$ & & & $\checkmark$ \\
\hline Masum, ctal [2015) & & & & & & v & v & & & & & & & & & & \\
\hline Suater, 2014). & & & & $\checkmark$ & & & & & & & & & & $v$ & & & $v$ \\
\hline Hosesian (2014) & & & & $v$ & & & & & & & & & $\checkmark$ & $v$ & & v & v \\
\hline Tilassume a t (2011) & $\checkmark$ & & & & & & & & & & & & & & & & \\
\hline Kartitikcyna cal (2010) & & & & & & & & $\mathrm{v}$ & & s & & $\mathrm{s}$ & & & & $\checkmark$ & s \\
\hline 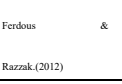 & & & v & & $\checkmark$ & & & & & & & $\checkmark$ & & $v$ & & & v \\
\hline
\end{tabular}

\section{Method}

The purpose of this paper is to assess whether the training programs conducted by government banks in Bangladesh are effective. We used an evaluative research design to evaluate training effectiveness. We used primary as well as secondary data to complete this article. Primary data were collected through a research questionnaire from the government bank employees who got trained by their banks and the secondary data were 
collected from journal articles, newspapers, and websites.

\subsection{Sample Design and Determination of Sample Size}

At present, there are nine public banks in Bangladesh. Among them, three are government-owned specialized banks that are currently operating their services besides six public commercial banks. The government-owned banks are (i) Sonali Bank Limited (ii) Basic Bank Limited (iii) Rupali Bank Limited (iv) Rajshahi Krishi Unnayan Bank (v) Probashi Kallyan Bank Limited (vi) Janata Bank Limited (vii) Bangladesh Krishi Bank (viii) Bangladesh Development Bank Limited and (ix) Agrani Bank Limited. We found from the literature that about 70119 employees are working in 9 state-owned banks of Bangladesh (Table 3).

Table 3. Total number of branches and employees in government banks of Bangladesh

\begin{tabular}{lllll}
\hline Sl. No. & Name of the Bank & Number of Branches & Total Employees & Year of Established \\
\hline 1. & Janata Bank & 912 & 12391 & 1971 \\
2. & Probashi Kallyan Bank & 64 & 1765 & 2010 \\
3. & Sonali Bank & 1215 & 21839 & 1972 \\
4. & Rupali Bank & 665 & 5150 & 1972 \\
5. & Rajshahi Krishi Unnayan Bank & 153 & 3,661 & 1987 \\
6. & Basic Bank Limited & 76 & 2103 & 1988 \\
7. & Bangladesh Krishi Bank & 973 & 9166 & 1973 \\
8. & Bangladesh Development Bank Limited & 32 & 775 & 2010 \\
9. & Agrani Bank Limited & 953 & 13269 & 1972 \\
Total Branches \& Employees in Public Banks & 5043 & 70119 & \\
\hline
\end{tabular}

We used Yamane's (1967) formula to determine the sample size for this paper.

$$
n=\frac{N}{1+N(e)^{2}}
$$

Where the study sample size is $\mathrm{n}$, the population size is $\mathrm{N}$, and the precision level is e. The precision level is presumed to be 0.07 and the population size was set 70119 for this paper. Putting these values into the aforementioned equation, the minimum number of sample size becomes approximately 203. This research interviewed 205 current employees of nine government banks to evaluate the training efficacy. This figure exceeds the critical sample size of 204 for performing multivariate analysis (Hair et al., 1998).

A convenience sampling technique was used to draw sample units by taking into consideration the employees' availability and willingness to respond to the survey (Malhotra, 2007).

\subsection{Questionnaire Design}

We used the structured questionnaire developed by Dabholkar (1996) in this paper for collecting data from the bank employees. Responses to all the statements in the questionnaire were measured on a 5-point scale ranging from 1 to 5 where 1 indicates strongly disagree and 5 indicates strongly agree. One of the relative advantages of using this scale is its suitability for the applications of multifarious statistical tools used in social research study (Malhotra, 1999). To get the necessary information, the collected data were statistically processed and analyzed subsequently. The reliability statistics illustrate that the internal consistency among the questionnaire items is under the acceptable range (Nunnally, 1978). The reliability statistics are at the acceptable level (Table 4).

Table 4. Reliability statistics of the data set

\begin{tabular}{ll}
\hline Cronbach's Alpha & N of Items \\
\hline 0.858 & 21 \\
\hline
\end{tabular}

\subsection{Data Collection \& Analysis}

Data of this study were collected from both primary and secondary sources. We used primary data to examine the effectiveness of employee training in government banks in Bangladesh. The survey questionnaires were circulated among the employees who had attended any training program before in the nine public banks in Bangladesh. The survey of this research was conducted in 2019. The interviewers were properly trained on the 
items included in the questionnaire for data collection before conducting the survey. We used descriptive statistics (Note 1), inferential statistical (Note 2) techniques such as Factor Analysis and Multiple Regression Analysis to analyze the respondents' data. A Principal Component Analysis (PCA) with an Orthogonal Rotation (Varimax) (Note 3) using the SPSS (Statistical Package for Social Sciences) software was performed on the recorded data. Multiple Regression Analysis (Note 4) such as, Multiple Regression was conducted using SPSS to identify the association between the predicted and observed variables and the significant factors.

\section{Analysis and Interpretations}

In the analysis section of this paper, multivariate analysis like factor analysis and multiple regression analysis were performed and interpreted.

\subsection{Results of Exploratory Factor Analysis (EFA)}

The outputs of the factor analysis demonstrated that all the variables related to the effectiveness of employee training in state-owned commercial banks of Bangladesh have high communalities indicating the variables are important in this study (Table 5).

Table 5. Communalities of the variables

\begin{tabular}{|c|c|c|}
\hline \multicolumn{2}{|c|}{ Variables } & \multirow{2}{*}{$\begin{array}{l}\text { Extraction } \\
.544\end{array}$} \\
\hline 1. & Induction training is given adequate importance in my bank & \\
\hline 2. & Training programs are well planned in this bank & .545 \\
\hline 3. & The duration of the training was sufficient to learn & .567 \\
\hline 4. & Norms and values of the organization are clearly explained to new employees during induction training & .585 \\
\hline 5. & Training programs are periodically reviewed and improved in my bank & .690 \\
\hline 6. & Employees acquired technical knowledge and skill through this training & .664 \\
\hline 7. & Employees participate in determining the training needs & .648 \\
\hline 8. & This bank provides training and development based on genuine needs & .711 \\
\hline 9. & Training and development (T\&D) increase the skill of employees & .698 \\
\hline 10. & T \& D enhance the quality of services being performed by employees & .663 \\
\hline 11. & Training \& development satisfy the ego of employees & 639 \\
\hline $\begin{array}{l}12 . \\
\text { empl }\end{array}$ & $\begin{array}{l}\text { Training and development programs enhance the efficiency and effectiveness of the work being perf } \\
\text { oyees }\end{array}$ & .667 \\
\hline 13. & The faults in operations can be minimized by training \& development & .606 \\
\hline 14. & Training improves the leadership and managerial skills of employees & .508 \\
\hline 15. & Training \& development reduce the stress level of employees & .756 \\
\hline 16. & Training and development stabilize the organization & .687 \\
\hline 17. & Training \& development of this bank help employees in promotion and other monetary benefits & .689 \\
\hline 18. & Training program was helpful in the long run & .751 \\
\hline 19. & Training program of our bank was helpful in personal growth & .725 \\
\hline 20. & Instructor's responses to trainees doubts were acceptable to me & .650 \\
\hline 21. & The Training system of this bank was excellent in my opinion & .672 \\
\hline
\end{tabular}

Extraction Method: Principal Component Analysis.

Table 6 illustrates the factors contributing to the effectiveness of employee training programs in the Bangladeshi public sector banks. The result demonstrates that the development of the overall skills of the employees, reduction of stress level, development of technical skills, need-based training programs, long-run productivity, and quality of the instructor are critical aspects for the efficacy of the employee training in the state-owned commercial banks of Bangladesh. The variance of factor named overall skills of the employees is the highest $(26.95 \%)$ led by reduction of stress level $(11.75 \%)$, development technical skills $(8.66 \%)$, need-based training programs $(7.34 \%)$, long-run productivity (5.39) and quality of the instructor $(4.96 \%)$. The total variance of the data set is $65.07 \%$ which depicts that a significant portion of the data set is included in the analysis. 
Table 6. Factors and total variance explained

\begin{tabular}{|c|c|c|c|c|}
\hline & & \multicolumn{3}{|c|}{ Initial Eigenvalues } \\
\hline \multicolumn{2}{|c|}{ Factors } & Total & $\%$ of Variance & Cumulative \% \\
\hline 1 . & Development of Overall Skills & 5.660 & 26.952 & 26.952 \\
\hline 2. & Reduction of Stress Level & 2.468 & 11.755 & 38.706 \\
\hline 3. & Development Technical Skills & 1.820 & 8.665 & 47.372 \\
\hline 4. & Need-Based Training Programs & 1.542 & 7.342 & 54.714 \\
\hline 5. & Long-run Productivity & 1.133 & 5.396 & 60.110 \\
\hline & Quality of Instructor & 1.042 & 4.962 & 65.072 \\
\hline
\end{tabular}

Extraction Method: Principal Component Analysis.

Table 7 indicates a very high factor loading of the variables which represented the factors. It indicates that all the variables' factor loadings are high suggesting that the correlation between the factors and the variables that represented the factor(s) are strong in nature. The higher absolute value of the variables' loading suggests that the study variables and the retained factors are closely interrelated. It simply means that the study variables play a greater significant role in interpreting the factor analysis.

Table 7 Rotated Component Matrix ${ }^{\mathrm{a}}$

\begin{tabular}{|c|c|c|c|c|c|c|}
\hline \multirow[b]{2}{*}{ Variables } & \multicolumn{2}{|c|}{ Factor Loadings } & \multirow[b]{2}{*}{3} & \multirow[b]{2}{*}{4} & \multirow[b]{2}{*}{5} & \multirow[b]{2}{*}{6} \\
\hline & 1 & 2 & & & & \\
\hline 1. Training and development (T\&D) increase the skill of employees & .769 & .096 & .141 & .225 & .058 & -.152 \\
\hline 2. T \& D enhance the quality of services being performed by employees & .744 & .038 & .200 & .249 & .079 & -.024 \\
\hline $\begin{array}{l}\text { 3. Training and development programs enhance the efficiency and } \\
\text { effectiveness of the work being performed by employees }\end{array}$ & d. 727 & .290 & -.032 & .121 & .008 & .197 \\
\hline 4. The faults in operations can be minimized by training \& development & .691 & .111 & -.065 & -.264 & .160 & .129 \\
\hline 5. Training \& development reduce the stress level of employees & .009 & .817 & -.007 & .213 & .194 & .071 \\
\hline 6. Training and development stabilize the organization & .196 & .778 & .045 & .027 & -.008 & .200 \\
\hline 7. Training improves the leadership and managerial skills of employees & .445 & .547 & .069 & -.029 & .069 & .018 \\
\hline 8. Training \& development satisfy the ego of employees & .355 & .516 & -.122 & .426 & .177 & .135 \\
\hline $\begin{array}{l}\text { 9. Employees acquired technical knowledge and skill through this } \\
\text { training }\end{array}$ & S. 192 & -.122 & .778 & .011 & .085 & .013 \\
\hline $\begin{array}{l}\text { 10. Training programs are periodically reviewed and improved in my } \\
\text { bank }\end{array}$ & $y-.070$ & .077 & .750 & .288 & -.049 & .178 \\
\hline $\begin{array}{l}\text { 11. Norms and values of the organization are clearly explained to new } \\
\text { employees during induction training }\end{array}$ & v.186 & .077 & .491 & .137 & -.461 & .268 \\
\hline 12. The Training system of this bank was excellent in my opinion & .030 & .250 & .482 & .110 & .439 & .413 \\
\hline $\begin{array}{l}\text { 13. This bank provides training and development based on genuine } \\
\text { needs }\end{array}$ & e. 181 & .030 & .114 & .803 & .133 & .034 \\
\hline 14. Employees participate in determining the training needs & -.126 & .124 & .389 & .615 & .283 & -.079 \\
\hline 15. Induction training is given adequate importance in my bank & .214 & .129 & .217 & .540 & .012 & .379 \\
\hline 16. Training program was helpful in the long run & .261 & .153 & .000 & .277 & .763 & .034 \\
\hline 17. Training program of our bank was helpful in personal growth & .117 & .067 & .014 & .304 & .728 & .290 \\
\hline $\begin{array}{l}\text { 18. Training \& development of this bank help employees in promotion } \\
\text { and other monetary benefits }\end{array}$ & n.088 & .503 & .177 & -.261 & .570 & -.064 \\
\hline 19. Instructor's responses to trainees doubts were acceptable to me & .067 & .072 & -.027 & -.037 & .108 & .792 \\
\hline 20. The duration of the training was sufficient to learn & -.066 & .103 & .319 & .116 & .001 & .661 \\
\hline $\begin{array}{l}\text { 21. Training programs are well planned in } \\
\text { this bank }\end{array}$ & .129 & .264 & .404 & .353 & .059 & .408 \\
\hline
\end{tabular}

Extraction Method: Principal Component Analysis.

Rotation Method: Varimax with Kaiser Normalization.

a. Rotation converged in 9 iterations.

\subsection{Results of Multiple Regression Analysis}

We conducted an Analysis of variance (ANOVA) test to analyze the cause and effect relationship between the independent variables and the dependent variable. ANOVA test demonstrates that all the six factors contributing to the effectiveness of employee training in government banks of Bangladesh are significantly related to the overall training impact on the bank employees of Bangladesh (Table 8). 
Table 8. ANOVA $^{\mathrm{a}}$

\begin{tabular}{lllllll}
\hline Model & & Sum of Squares & df & Mean Square & F & Sig. \\
\hline 1 & Regression & 155.171 & 6 & 25.862 & 43.431 & $.000^{\mathrm{b}}$ \\
& Residual & 110.757 & 186 & .595 & & \\
& Total & 265.927 & 192 & & \\
\hline
\end{tabular}

a. Dependent Variable: Considering all the factors mentioned above, I think the training I have attended was highly effective

b. Predictors: (Constant), REGR factor score 6 for analysis 1 , REGR factor score 5 for analysis 1 , REGR factor score 4 for analysis 1 , REGR factor score 3 for analysis 1 , REGR factor score $\quad 2$ for analysis 1 , REGR factor score 1 for analysis 1

The second output of the multiple regression analysis is the model summary table which illustrates the strength of the association between the factors and the model. Here R known as the multiple correlation coefficient is 0.764 indicates a strong correlation between the model variables, Model summary also shows that the adjusted $\mathrm{R}$ square is 0.570 that indicates these six factors explain $57 \%$ of the total variation of the predicted variable. The result of the model summary demonstrates a higher level of association of the factors with the overall effectiveness of the employee training in government banks of Bangladesh (Table 9).

Table 9. Model Summary

\begin{tabular}{llllll}
\hline & & & & Std. Error of the \\
Model & $\mathrm{R}$ & R Square & Adjusted R Square & Estimate & F Change \\
\hline 1 & $.764^{\mathrm{a}}$ & .584 & .570 & .77167 & 43.431 \\
\hline
\end{tabular}

Table 10 shows that the factors such as reduction of stress level, development technical skills, need-based training programs, long-run productivity, and quality of the instructor have a significant association with the overall training effectiveness of the government banks in Bangladesh. Factor such as development of overall skills of the employees was not found significant in public banks of Bangladesh.

Table 10. Coefficients

\begin{tabular}{|c|c|c|c|c|c|}
\hline \multirow[b]{2}{*}{ Model } & \multicolumn{2}{|c|}{ Unstandardized Coefficients } & \multirow{2}{*}{$\begin{array}{l}\text { Standardized } \\
\text { Coefficients } \\
\text { Beta }\end{array}$} & \multirow[b]{2}{*}{$\mathrm{t}$} & \multirow[b]{2}{*}{ Sig. } \\
\hline & $\mathrm{B}$ & Std. Error & & & \\
\hline (Constant) & 2.896 & 0.056 & & 52.144 & .000 \\
\hline 1. Development of Overall Skills & 0.034 & 0.056 & 0.032 & 0.683 & .495 \\
\hline 2. Reduction of Stress Level & 0.338 & 0.056 & 0.287 & 6.064 & .000 \\
\hline 3. Development Technical Skills & 0.530 & 0.056 & 0.450 & 9.517 & .000 \\
\hline 4. Need-Based Training Programs & 0.296 & 0.056 & 0.252 & 5.324 & .000 \\
\hline 5. Long Run Productivity & 0.229 & 0056 & 0.195 & 4.117 & .000 \\
\hline 6. Quality of Instructor & 0.521 & 0.056 & 0.443 & 9.353 & .000 \\
\hline
\end{tabular}

a. Dependent Variable: 23. Considering the above situations as a whole my social and economic status has been increased after starting this business (Self evaluate)

The residual standard deviation is a statistical concept used to characterize the standard deviation of points developed along a linear equation and is a prediction of the precision of the latent variable being measured. Residuals statistics of this research represent that the standard deviations of predicted value, residual, std. predicted value and std. residuals are likely to be less than one. The Normal P-P Plot of Regression Results of the analysis has been illustrated in Figure 1. 


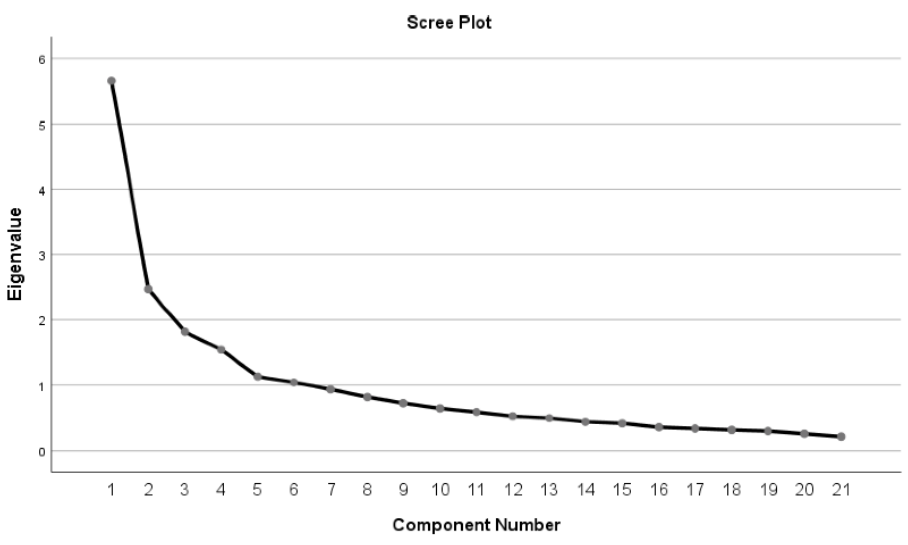

Figure 1. Normal P-P Plot of regression results

\section{Limitations and Direction for Future Research}

We acknowledge some limitations associated with our research paper. The first limitation is the nature of the sampling of respondents as the research did not include employers and top management executives though they have a significant role to play in training effectiveness. It would be better to include both employees and employers to evaluate the training effectiveness in the Government banks of Bangladesh. Another major limitation of this paper is that the HR departments of the banks did not disclose the internal training feedbacks and reports. However, there is an ample scope for future researchers to conduct a more in-depth analysis of this topic by considering more samples in the future. Future research may include both trainees and trainers to assess the effectiveness of training programs. Despite the limitations of this paper, our findings contribute significantly to the existing literature which can be impactful for the bank management.

\section{Conclusion and Policy Implications}

This study attempted to assess the effectiveness of employee training and development programs conducted in the government banks of Bangladesh. In this paper, six factors were identified associated with the overall training effectiveness in the public banks. These six factors were retained from factor analysis as they had higher eigenvalues. The test of ANOVA demonstrated that all the retained six factors are significant to the regression model. Model summary represented that the adjusted R square is 0.570 which indicates a strong association of the factors with the overall training efficacy in government banks. The factors such as reduction of stress level, development technical skills, need-based training programs, long-run productivity, and quality of the instructor have a significant association with the overall training effectiveness of the government banks of Bangladesh. Factor like the development of the overall skills of the employees does not have a significant relationship with the training effectiveness in public banks of Bangladesh. This paper finds that training programs that reduce the stress level of the employees at the workforce tend to be more effective. An effective training session must help the staff to develop new technical or soft skills. Training programs have to be need-based and the HR department should analyze the need for the required training beforehand. A successful training and development program has to increase the productivity of the manpower in the long run by boosting their performance. And finally, the training provider has to ensure the quality of the trainer to get the highest output from the employees of the bank.

The training effectiveness factors reported in this paper are evident to have serious policy implications. The top management of the public banks of Bangladesh should emphasize on the reduction of stress level, development of technical skills, need-based training programs, training programs which increases productivity in the long run, and the quality of the instructor for the effectiveness of the employee training in public banks of Bangladesh.

\section{References}

Afroj, S. (2012). Ongoing corporate human resource management practice in banking sector of Bangladesh. Global Journal of Management and Business Research, 12(2).

Ahmed, S., \& Uddin, N. M. (2012) Job Satisfaction of Bankers and its Impact in Banking: A Case Study of Janata Bank. ASA University Review, 6(2).

Akilandeswari, P. (2014). A study on Effectiveness of training in Indian Banks. International Journal of Recent Advances in Organizational Behavior and Decision Sciences (IJRAOB), 1(1), 85-99. 
Akter, S., Sachu, K. M., \& Md., A. E. (2012) .The Impact of Rewards on Employee Performance in Commercial Banks of Bangladesh: An Empirical Study. Journal of Business and Management (IOSR-JBM), 6(2) 9-15. https://doi.org/10.9790/487X-0620915

Athar, R., \& Shah, M. F. (2015). Impact of Training on Employee Performance (Banking Sector Karachi). IOSR Journal of Business and Management (IOSR-JBM).

Chahal, A. (2013). A Study of Training Need Analysis Based Training and Development: Effect of Training on Performance by Adopting Development Based Strategy. International Journal of Business and Management Invention, 2(4), 41-51.

Ferdous, T., \& Razzak, M. B. (2012) Importance of Training Needs Assessment in the Banking Sector of Bangladesh: A Case Study on National Bank Limited (NBL). International Journal of Business and Management, 7(10). https://doi.org/10.5539/ijbm.v7n10p63

Hossain, A. M. (2014). An Overview on Effective Employee Training Systems of Private Sector Commercial Banks in Bangladesh. International Journal of Ethics in Social Sciences, 2(1).

Islam, M. Z. (2015). Efficiency of training: a comparative study on some selected commercial banks in Bangladesh. Journal of Asian Business Strategy, 5(6), 116-124.

Karthikeyan, K., Karthi, R., \& Graf, D. S. (2010). Impact of Training in Indian Banking Sector-An Empirical Investigation. International Journal of Business and Management, 5(7), 77. https://doi.org/10.5539/ijbm.v5n7p77

Kaur, M. (2016). An Empirical Study on Effectiveness of Training Programs among Women Employees in Public and Private Sector Banks. Ushus J B Mgt 15(2), 1-22. https://doi.org/10.12725/ujbm.35.1

Lamba, S., \& Choudhary, N. (2013) Impact of HRM Practices on Organizational Commitment of Employees. International Journal of Advancements in Research \& Technology, 2(4), 407-423.

Mahmood, F., Iqbal, N., \& Sahu, R. S. (2014). The Impact of Human Resource Management Practices on Employee Performance in Banking Industry of Pakistan. Euro-Asian Journal of Economics and Finance, 2(1), 86-99.

Malhotra, N. K. (1999). Marketing Research: An Applied Orientation. Englewood Cliffs, NJ: Prentice-Hall.

Malhotra, N. K. (2007). Marketing Research - An Applied Orientation. Pearson Education, India.

Masum, A. K. M., Azad, M. A. K., Hoque, K. E., \& Beh, L. S. (2015). Domestic banks in Bangladesh could ensure efficiency by improving human resource management practices. PloS one, 10(7), e0121017. https://doi.org/10.1371/journal.pone.0121017

Megharaja, B. M. (2014). The Effectiveness of Training and Development in Banking Sector- A Case Study of State Bank of India. EPRA International Journal of Economic and Business Review, 2(9).

Mohamed, R., \& Alias, S. A. A. (2012) Evaluating the Effectiveness of a Training Program Using the Four Level Kirkpatrick Model in the Banking Sector in Malaysia. Retrieved from https://www.researchgate.net/publication/265425958

Rahman, H. (2014). Training and Job Satisfaction For Organizational Effectiveness: A Case Study From The Banking Sector. Central European Business Review, 3(1). https://doi.org/10.18267/j.cebr.72

Sarker, A. R. (2014). Increasing employee job satisfaction as well as organizational performance through effective HRM practices in private commercial banking sector of Bangladesh. Journal of Economics and Sustainable development, 5(10), 157-165.

Tabassum, A., Rahman, T., \& Jahan, K. A. (2011). Comparative Analysis of Quality of Work Life among the Employees of Local Private and Foreign Commercial Banks in Bangladesh. World Journal of Social Sciences, 1(1), 17-33.

Taro, Y. (1967). Statistics: An introductory analysis. New York: Harper and Row.

\section{Copyrights}

Copyright for this article is retained by the author(s), with first publication rights granted to the journal.

This is an open-access article distributed under the terms and conditions of the Creative Commons Attribution license (http://creativecommons.org/licenses/by/4.0/). 